Western University Scholarship@Western

Department of Economics Research Reports

Economics Working Papers Archive

1978

\title{
Female Labour Supply and Fertility in Canada
}

Geoffrey Carliner

Chris Robinson

Nigel Tomes

Follow this and additional works at: https://ir.lib.uwo.ca/economicsresrpt

Part of the Economics Commons

Citation of this paper:

Carliner, Geoffrey, Chris Robinson, Nigel Tomes. "Female Labour Supply and Fertility in Canada." Department of Economics Research Reports, 7837. London, ON: Department of Economics, University of Western Ontario (1978). 
RESEARCH REPORT 7837

FEMALE LABOUR SUPPLY AND FERTILITY

IN CANADA

by

Geoffrey Carliner

Christopher Robinson

Nigel Tomes

December, 1978

Depertment of Economics Library

NOV 21983

Uaivarsity of Hitestem Ontario 
FEMALE LABOUR SUPPLY AND FERTILITY IN CANADA*

\author{
Geoffrey Carliner \\ Christopher Robinson \\ and \\ Nigel Tomes \\ University of Western Ontario \\ London, Ontario, Canada \\ N6A $5 \mathrm{C} 2$
}

* An earlier version of this paper was presented at the Econometric Society Meetings, August 28-31, 1978, Chicago, Illinois, U.S.A. 
Female Labour Supply and Fertility in Canada

\section{Introduction}

The theory of the allocation of time in Becker (1965) and the subsequent development with this framework of the new microeconomic theory of fertility In Schultz (1973), especially Willis (1973), imply that family labour supply and fertility decisions are jointly determined. However, most empirical work has analyzed these two variables separately. While acknowledging possible simultaneity, most economists have treated fertility as an exogenous determinant of labour supply, and demographers have assumed that labour supply is an exogenous determinant of fertility. In Canada, Ostry (1968), Davies (1969), Spencer (1973), Skoulas (1974), and Gunderson (1977) have done the former, while Balakrishnan et al. (1975, 1978), Collishaw (1976), and Henripin (1972) have analyzed the latter. These studies have generally used some type of multiple regression technique on cross section data, usually from the decennial Census or from the Survey of Consumer Finances .

However, Da Vanzo (1972), Schultz, Maurer, and Ratajczak (1973), Cain and Dooley (1976), Rosenzweig and Evenson (1977), and Conger and Campbell (1978) have estimated simultaneous models of fertility and labour supply. These latter papers have all used data for the U.S. or, more often, from developing countries, on area rather than individual cross sections. Frequently life cycle as well as lifetime variables were included in the estimated equations without a clear explanation of the factors affecting timing over the life cycle.

The present paper develops a household production model in which the choice of numbers of children and labour supply is simultaneous. To focus on completed family size and the amount of market work over the entire lifetime, rather than on the timing of births and market work over the life cycle, we use a one period lifetime model. The parameters of this model are estimated on 1971 Canadian 
Census data. Our estimation techniques account for the fact that children can only be produced in discrete units, that labour force participation is dichotomous, and that observed hours and weeks worked are concentrated at zero.

II. A One Period Lifetime Model

Families are assumed to maximize a utility function of the form:

$\mathrm{U}=\mathrm{U}(\mathrm{n}, \mathrm{Z}, \mathrm{e})$

where $\mathrm{n}$ is the number of children, assumed to be produced with the use of female time $\left(C_{f}\right)$, male time $\left(C_{m}\right)$ and market goods $(X)$ according to the technological constraint

$$
\mathrm{n}=\mathrm{n}\left(\mathrm{C}_{\mathrm{f}}, \mathrm{C}_{\mathrm{m}}, \mathrm{x}\right)
$$

$Z$ represents a composite of all other commodities produced in the household using inputs of female and male time $\left(H_{f}\right.$ and $H_{m}$, respectively) and market goods $(y)$ :

$$
\mathrm{Z}=\mathrm{Z}\left(\mathrm{H}_{\mathrm{f}}, \mathrm{H}_{\mathrm{m}}, \mathrm{y}\right)
$$

and $e$ is a randomly distributed taste variable. Joint production is excluded, and all women are assumed to work in the labour market at some point in their lifetime. The functions (2) and (3) we assumed to be linearly homogeneous. Families maximize utility subject to a lifetime "full" wealth constraint obtained by substituting the constraints on time inputs (4), into the incomeexpenditure constraint (5):

$$
\begin{aligned}
& \mathrm{C}_{\mathrm{f}}+\mathrm{H}_{\mathrm{f}}+\mathrm{L}_{\mathrm{f}}=\mathrm{T}_{\mathrm{f}} \\
& \left.C_{m}+H_{m}+I_{m}=T_{m}\right\} \\
& p_{x} x+p_{y} y=w_{f} L_{f}+w_{m} L_{m}+v
\end{aligned}
$$


where $V$ is non-labour income, $L_{f}$ and $L_{m}$ represent the time supplied to the market by female and male, respectively, $w_{f}$ and $w_{m}$ denote the respective wage rates and $p_{x}$ and $p_{y}$ represent the market prices of the goods inputs $x$ and $y$. The lifetime "full" wealth constraint is therefore:

$$
p_{x} x+p_{y} y+w_{f}\left(C_{f}+H_{f}\right)+w_{m}\left(C_{m}+H_{m}\right)=w_{f} T_{f}+w_{m} T_{m}+V \equiv S
$$

Maximizing (1) subject to (6) and non-negativity constraints on inputs, yields first-order conditions necessary for an (assumed) interior maximum from which demands for $\mathrm{n}$ and $\mathrm{Z}$ can be obtained as functions of total full wealth $\mathrm{S}$ the prices of time and market inputs, and tastes. Since full wealth is a function of nonlabour income $(V)$ and the prices of time (equal to market wage rates $w_{f}$ and $w_{m}$ because of the assumed interior solution in lifetime hours of work), we can write the demand functions for children and other household goods 1

$$
\begin{aligned}
& n=n\left(w_{f}, w_{m}, p_{x}, p_{y}, v, e\right) \\
& z=z\left(w_{f}, w_{m}, p_{x}, p_{y}, v, e\right)
\end{aligned}
$$

Utility maximization subject to the full income budget constraint also yields demand functions for factors, i.e., for inputs of time and market goods into the production of child services and other household goods. These demands are also functions of market wage rates, prices of market goods, nonlabour income, and tastes. Finally, since the supply of labour to the market must equal total available time minus time allocated to household production (1.e., $L_{j}=T-C_{j}-H_{j}$ for $\left.j=m, f\right)$ we can also write female labour supply as a function of prices, nonlabour income, and tastes.

$$
L_{f}=L\left(w_{f}, w_{m}, P_{x}, P_{y}, V, e\right)
$$


In order to investigate the signs of the reduced form coefficients in (7) and (9) it is convenient to write them in $\log$ derivative form as follows:

$$
\begin{aligned}
& d \ln n=\left[s_{L}^{f} \eta_{n}-s_{Z} \sigma\left(k_{n}^{f}-k_{Z}^{f}\right)\right] d \ln w_{f}+\left[s_{L}^{m} \eta_{n}+s_{Z} \sigma\left(k_{Z}^{m}-k_{n}^{m}\right)\right] d \ln w_{m} \\
& +s_{v} \eta_{n} d \ln v-k_{x}\left(s_{n} \eta_{n}+s_{z} \sigma\right) d \ln p_{x}+s_{y}\left(\sigma-\eta_{n}\right) d \ln p_{y} \\
& d \ln L^{f}=\left(s_{L}^{f}\right)^{-1}\left\{\left[s_{n} s_{Z} \sigma\left(k_{Z}^{f}-k_{n}^{f}\right)^{2}+\left(1-k^{f}\right) \psi-s_{L}^{f} s_{J} \eta_{J}\right] d \ln w_{f}\right. \\
& -\left[s_{L}^{m} s_{J} \eta_{J}+s_{n} s_{Z} \sigma\left(k_{n}^{f}-k_{Z}^{f}\right)\left(k_{Z}^{m}-k_{n}^{m}\right)+k^{m} m^{m}\right] d n w_{m} \\
& -s_{V} s_{J} \eta_{J} \cdot d \ln v_{+} s_{x}\left[s_{J} \eta_{J}+s_{Z} \sigma\left(k_{n}^{f}-k_{Z}^{f}\right)-k_{n}^{f} \psi\right] d \ln p_{x} \\
& +s_{y}\left[s_{J} \eta_{J}-s_{n} \sigma\left(k_{n}^{f}-k_{z}^{f}\right)-k_{z}^{f} \psi d \ln p_{y}\right\}
\end{aligned}
$$

where: $s_{i}=\frac{\pi_{i}}{s}\left(e \cdot g \cdot, s_{n}=\frac{\pi_{n} n}{s}, s_{L}^{f}=\frac{w_{f} L^{f}}{s}\right.$, etc. $)$

$k_{j}^{i}=\frac{p_{i}^{i}}{\pi_{j} j}\left(e \cdot g \cdot: \quad k_{n}^{f}=\frac{w_{f} C_{f}}{\pi_{n} n}\right.$, etc. $)$

$\eta_{j}=$ full income elasticity of commodity $j$

$\sigma=$ the elasticity of substitution between $Z$ and $n$

$\psi=$ the elasticity of substitution in production (assumed to be the same between every pair of inputs in each production function--an assumption which excludes the possiblity of compliamentarity in production)

$s_{J} \eta_{J} \equiv\left[k_{n}^{f} s_{n} \eta_{n}+k_{Z}^{f} s_{Z} \eta_{Z}\right]$ the full income elasticity of demand for the wife's non-market time $\left(J=\mathrm{C}_{\mathrm{f}}+\mathrm{H}_{\mathrm{f}}\right)$

$\left(1-k^{f}\right) \equiv\left[k_{n}^{f} s_{n}\left(1-k_{n}^{f}\right)+k_{Z}^{f} s_{Z}\left(1-k_{Z}^{f}\right)\right]$

$k^{m} \equiv\left[k_{n}^{f} s_{n} k_{n}^{m}+k_{z}^{f} s_{z} k_{z}^{m}\right]$ 
In the demand function for child numbers we have the following results. If children are "wife's-time intensive" (i.e., $k_{n}^{f}>k_{Z}^{f}$ ) the effect of $w_{f}$ is ambiguous, being negative if the substitution effect dominates the income effect. An increase in $w_{m}$ will raise $n$ if children are not husband's time intensive (i.e., $k_{Z}^{m}>k_{n}^{m}$, which need not be the case even if $k_{n}^{f}>k_{Z}^{f}$ since we have 3 inputs). An increase in $\mathrm{V}$ will raise $\mathrm{n}$ if children are normal (i.e., $\eta_{n}>0$; however in terms of a quality-quantity interaction model $\eta_{h}$ is a "reduced form" income elasticity which may be negative even if children are a superior commodity). An increase in $\mathrm{P}_{\mathrm{x}}$ unambiguously reduces $\mathrm{n}$. The effect of $\mathrm{p}_{\mathrm{y}}$ depends on the cross-price elasticity and is thereforeambiguous.

Regarding the labour supply schedule the following results obtain: An increase in $w_{f}$ results in (i) a substitution effect in consumption $(\sigma)$ that is positive (ii) substitution effect in production ( $\psi$ ) (positive) (ii) an income effect $\left(\eta_{J}\right)$ (negative). If the substitution effects (i) and (ii) outweigh the income effect (iii) (as is typically the case for women) an increase in $w_{f}$ raises $L^{f}$. The effect of an increase in $w_{m}$ is in general ambiguous, since $\left(k_{n}^{f}-k_{z}^{f}\right)\left(k_{z}^{m}-k_{n}^{m}\right) \gtreqless 0$. If $k_{n}^{f}>k_{z}^{f}$ and $k_{z}^{m}>k_{n}^{m}$ (i.e., the cost shares of wife's and husband's times are negatively related--a "plausible" case) then an increase in $w_{m}$ has 3 effects $(i)$ an income effect increasing demand for wife's home-time (reducing $\mathrm{L}^{\mathrm{f}}$ ) (ii) a substitution effect in consumption--reducing the relative price of the wife-time intensive commodity $\left(\pi_{n} / \pi_{2}\right)$--which also increases the demand for her home-time (reducing $L^{f}$ ) and (iii) substitution in production out of husband's time into wife's time (reducing $L^{f}$ ). Hence the coefficient on $w_{m}$ is $<0$. An increase in $V$ reduces labour supply $\left(\eta_{J}>0\right.$ unless the wife's time-intensive commodity were sufficiently inferior). The effect of an increase in $\mathrm{P}_{\mathrm{X}}$ on $\mathrm{L}^{\mathrm{f}}$ is ambiguous. An increase in $\mathrm{P}_{\mathrm{X}}$ has three effects 
(i) it reduces full income and therefore increases labour supply (ii) it raises the relative price of numbers $\left(\pi_{n} / \pi_{Z}\right)$ and hence increases $L^{f}$ if children are time-intensive (i.e., $k_{n}^{f}>k_{Z}^{f}$ ). But (iii) also leads to substitution in the production of $n$ out of $x$ and into $C_{f}$ which decreases labour supply. The effect of an increase in $\mathrm{p}_{\mathrm{y}}$ is also ambiguous. In summary, if $k_{n}^{f}>k_{z}^{f}, k_{n}^{m}<k_{z}^{m}$ and $\eta_{n}>0$ the predictions for (7) and (9) are as follows:

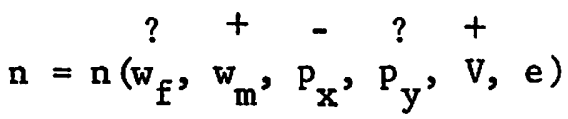

$$
\begin{aligned}
& \left.L^{f}=L^{f} \stackrel{?}{\left(w_{f}\right.}, \stackrel{+}{w_{m}}, \bar{V}, p_{x}, \stackrel{?}{p_{y}}, e\right)
\end{aligned}
$$

Note that the number of children does not appear in the labour supply equation. In general, when the demand for children and the allocation of time are simultaneously determined, it is not appropriate to include the one in the demand function of the other. Including numbers in the labour supply equation might be sensible when fertility is assumed exogenous, in multiperiod life cycle models, or in models in which parents choose both the quality and quantity of children. However, in a one period lifetime model in which numbers and hours are simultaneously determined, including $\mathrm{n}$ in the labour supply equation would be similar to including apple consumption rather than the price of apples in a demand function for oranges. While it is possible to derive from a one period model a simultaneous system consisting of (7) and a "structural" labour supply equation containing $n$, but excluding one of the exogenous variables (in order to identify it) the "structural" coefficients are of little interest since they summarize reactions to experimental changes in the exogenous variables which are of little practical interest--say a change in $w_{f}$ coupled with a compensated change in the excluded exogenous variable so as to hold $n$ fixed. ${ }^{12}$ 
Another variable often found in fertility and labour supply functions-age--also does not appear in equations (7) and (9). Because this is a one period model designed to analyze the number of children borne and the quantity of labour supplied over the entire lifetime, the age of the woman or her children have no place in these equations. Although life cycle questions regarding the spacing of births and of labour supply over the lifetime are also interesting, they are not the questions addressed here. Since age has no effect on lifetime fertility and labour supply choices (except for possible cohort effects ignored in this paper), it is not included as an independent variable here, and should not be included in other one period simultaneous models as some previous investigators have done (see for instance, Cain and Dooley (1976)).

\section{Empirical Specification}

In order to estimate the fertility (7) and labour supply (9) equations, we must first specify price equations for market inputs to child services $\left(p_{x}\right)$ and to other household goods $\left(p_{y}\right)$ in terms of observable variables. $P_{y}$ is assumed to be constant across families in the same period, but the price of nontime inputs to the production of children may vary by location and religion. Because of differences in the possibility of child employment and locally produced public and private goods, we hypothesize that the cost of raising children is successively lower in small towns, in rural areas, and on farms than in cities. ${ }^{3}$ Because the psychic price of using efficient birth control techniques in order not to have children may be higher for Catholics, we also hypothesize that the cost of having children may be lower for them than for nonCatholics. Therefore we specify

$$
\mathrm{P}_{\mathbf{x}}=\mathrm{p}(\text { Farm, Rural, Town, City, Catholic) }
$$

Although the woman's wage rate $\left(w_{f}\right)$ is in theory observable, in the one period data we use to estimate the model, no potential market wage was 
recorded for women not working at the time of the survey. While a wage rate could be imputed to these women based on the wage rates of working women, this procedure would result in a sample selection bias requiring corrections suggested by Heckman (1977) or Griliches, Hall, and Hausman (1977). However, the poor quality of the female wage rate in the Canadian Census makes a successful application of such correction procedures extremely unlikely. ${ }^{4}$ Our solution therefore is to specify an equation to the wife's wage $\left(w_{f}\right)$. We hypothesize that the wife's wage may be affected by her region of residence (Reg), that the higher her education $\left(E_{f}\right)$ the higher her wage, and that membership in a major language group (Lang) implies a higher marginal product, and hence wage, in the Canadian labour market, than for minority language group members:

$$
w_{f}=w_{f}\left(E_{f}, \text { Reg, Lang }\right)
$$

Substituting the determinants of the wife's wage (11) and the price variables (10) Into the fertility (7) and labour supply (9) equations, we obtain the estimating equations

$$
\begin{aligned}
& n=n\left(E_{f} \text {, Reg, Lang, } w_{m}\right. \text {, Farm, Rural, Town, City, Catholic, V,e) } \\
& L_{f}=I_{f}\left(E_{f} \text {, Reg, Lang, } w_{m} \text {, Farm, Rural, Town, City, Catholic, } V, e\right)
\end{aligned}
$$

The next problem is the empirical measure of 1abour supply. Theoretically this is the fraction of the woman's lifetime spent in the market. The measures of labour supply available in the Canadian census are: (i) current participation status, (ii) weeks worked last year and (iii) "normal" hours per week. Heckman (1978) discusses the conditions under which (i) can be. used to estimate the parameters of the lifetime labour supply equation. In general, these conditions are unlikely to be met. A variety of measures of labour supply were used in the estimation. 
A third problem is the discrete character of the fertility variable. In virtually all the studies that use micro-data to analyze the determinants of fertility, this problem is ignored. ${ }^{5}$ We have therefore estimated (12) using OLS and a logistic procedure. Similarly, the labour force participation of the wife is a discrete variable and therefore probit or logit techniques are appropriate. Also, since a considerable proportion of the observations have zero hours and weeks worked, labour supply equations using these measures should be estimated with a Tobit procedure.

\section{Empirical Results}

This section reports empirical results based on the 1971 Canadian Census one in a thousand sample. Several sample selection criteria were used in this study. To obtain a completed fertility cohort, only married women between 35 and 60 years of age who were living with their husbands were included. To obtain an observable male wage, the husband's annual earnings had to exceed $\$ 1000$ and his reported "normal" hours and weeks of work had to be positive. The resulting sample included 2153 women.

To estimate the fertility and labour supply equations, we ran regressions with dependent variables number of children ever born (NKIDS) and three measures of labour supply, female labour force participation during the week preceding the Census survey (IFP), hours usually worked per week, and weeks worked during 1970. The independent variables included the husband's wage rate, the family's nonlabour income, the wife's years of completed schooling, and dummy variables for six regions or provinces, two language groups, three size of place groups, and for being Catholic. The reference group was nonCatholic English speaking residents of cities in British Columbia. Table 1 defines all dependent and independent variables used in the regressions. We recognize that linear regression techniques are inappropriate when the dependent variable is discrete or concentrated at zero. However, for 
TABLE 1

DEFINITION OF VARIABLES

Theoretical Variable

Fertility (n)
Labour Supply $\left(\mathrm{L}_{\mathrm{f}}\right)$
Education $\left(\mathrm{E}_{\mathrm{f}}\right)$
Wage
V

Catholic

Lang

Reg

City

Town

Rural

Farm
Number of Children Ever Born

Labour Force Participation of Wife

Weeks Worked by Wife in 1970

Hours Usually Worked by Wife

Level of Schooling of Wife

Wage of Husband (Annual Earnings $\div$ Annual

Hours Worked in 1970) in Dollars

Non-labour Income (Total Family Income

Less Total Family Earnings) in \$000's

Religion of Wife $=$ Roman Catholic

Catholic

Mother Tongue
of Wife $\left\{\begin{array}{l}\text { English } \\ \text { French } \\ \text { Other }\end{array}\right.$

ENGLISH

FRENCH

IANGOTH

NKIDS

LFP

WEEKS

HOURS

$\mathrm{Ed}_{\mathrm{f}}$

$\mathbf{W}_{\mathbf{m}}$

NLABINC
Mnemonic

Newfoundland

Maritime Provinces

(Nova Scotia, New Brunswick)

Region of

Residence

Quebec

Ontario

Prairie Provinces (Manitoba, Alberta, Saskatchewan)

British Columbia

1971 Residence in city/town pop. $\geq 30,000$ City

1971 Residence in city/town pop. $<30,000$ Town

1971 Rural Non-Farm Residence

RNF

1971 Farm Residence

FARM 
comparison with estimates using alternative techniques, Table 2 reports oLs "benchmark" regressions of the fertility and labour supply equations using alternative dependent variables 。

In the fertility regression, the coefficients on nonlabour income and the husband's wage were both positive but insignificant. However, the four variables designed to proxy the price of children all were significant with the expected sign. Women in larger towns and cities have the smallest families. Women in towns under 30,000 have an average of 0.2 more children, rural nonfarm women have 0.56 additional children, and farm women have .94 more children. Catholic women have on aver age .7 children more than similar nonCatholics. (Other regressions, not shown, indicate that differences in fertility among other religions are small and insignificant.)

The coefficients on variables included in the fertility regression to reflect the wife's wage rate suggest that an increase in the value of the wife's time decreases the demand for children, presumably because children are wife's time intensive so that an increase in $w_{f}$ raises $\pi_{n} / \pi_{z}$. The education coefficient is negative and significant, and the only significant positive region coefficient is for Newfoundland, where wages are presumably lower than elsewhere in Canada. An alternative interpretation, following Michael (1973) and others, includes education as an efficiency augmenting variable in the two household production functions. Under this specification, the present result would imply that education decreases fertility by increasing the marginal product of female time in other household activities ( $Z$ ) by more than it increases the marginal product of time in the production of children. 
TABLE 2

OLS Fertility and Labour Supply Regressions

\begin{tabular}{|c|c|c|c|c|}
\hline & NKids & LFP & Hours & Weeks \\
\hline $\mathrm{Ed}_{\mathrm{f}}$ & $\begin{array}{c}-.053 \\
(-4.052)\end{array}$ & $\begin{array}{c}.018 \\
(4.940)\end{array}$ & $\begin{array}{c}.525 \\
(3.732)\end{array}$ & $\begin{array}{c}.751 \\
(4.670)\end{array}$ \\
\hline Newfoundland & $\begin{array}{c}.871 \\
(2.968)\end{array}$ & $\left(\begin{array}{l}.001 \\
.012)\end{array}\right.$ & $\left(\begin{array}{l}.011 \\
.003)\end{array}\right.$ & $\begin{array}{l}-1.112 \\
(.307)\end{array}$ \\
\hline Maritimes & $\left(\begin{array}{l}.014 \\
.073)\end{array}\right.$ & $\begin{array}{l}.037 \\
(.714)\end{array}$ & $\begin{array}{l}3.844 \\
(1.902)\end{array}$ & $\begin{array}{l}.144 \\
.062)\end{array}$ \\
\hline Quebec & $\begin{array}{c}-.203 \\
(-1.225)\end{array}$ & $\begin{array}{l}-.012 \\
(-.258)\end{array}$ & $\begin{array}{l}.229 \\
(.128)\end{array}$ & $\begin{array}{l}-2.410 \\
(1.177)\end{array}$ \\
\hline Ontario & $\left(\begin{array}{l}.008 \\
.059)\end{array}\right.$ & $\begin{array}{c}.130 \\
(3.640)\end{array}$ & $\begin{array}{l}4.489 \\
(3.208)\end{array}$ & $\begin{array}{c}3.676 \\
(2.297)\end{array}$ \\
\hline Prairies & $\begin{array}{l}.073 \\
(.476)\end{array}$ & $\left(\begin{array}{c}.087 \\
(2.082)\end{array}\right.$ & $\begin{array}{l}5.348 \\
(3.257)\end{array}$ & $\begin{array}{c}2.685 \\
(1.429)\end{array}$ \\
\hline French & $\left(\begin{array}{l}.067 \\
. .443\end{array}\right)$ & $\begin{array}{l}-.033 \\
(-.787)\end{array}$ & $\begin{array}{c}-.413 \\
(-.254)\end{array}$ & $\begin{array}{l}-.840 \\
(.451)\end{array}$ \\
\hline Othlang & $\frac{-.381}{(-3.447)}$ & $\left(\begin{array}{l}.016 \\
(.527)\end{array}\right.$ & $\left(\begin{array}{l}1.441 \\
1.209)\end{array}\right.$ & $\begin{array}{c}1.854 \\
(1.361)\end{array}$ \\
\hline $\mathrm{w}_{\mathrm{m}}$ & $\left(\begin{array}{l}.005 \\
. .612\end{array}\right)$ & $\begin{array}{l}-.007 \\
(-2.989)\end{array}$ & $(-.251)$ & $\begin{array}{l}-.323 \\
(3.279)\end{array}$ \\
\hline Nlabinc & $\left(\begin{array}{c}.022 \\
1.071)\end{array}\right.$ & $\begin{array}{l}-.002 \\
(-.327)\end{array}$ & $\begin{array}{l}.176 \\
(.794)\end{array}$ & $\left(\begin{array}{l}.201 \\
.796)\end{array}\right.$ \\
\hline Catholic & $\left(\begin{array}{c}.711 \\
(7.019\end{array}\right)$ & $\begin{array}{c}-.033 \\
(-1.177)\end{array}$ & $\begin{array}{c}-.698 \\
(-.639)\end{array}$ & $-.971)$ \\
\hline Farm & $\left(\begin{array}{c}.943 \\
6.324)\end{array}\right.$ & $\left(\begin{array}{l}.007 \\
. .181)\end{array}\right.$ & $\begin{array}{l}4.745 \\
(2.953)\end{array}$ & $\begin{array}{c}1.078 \\
(.586)\end{array}$ \\
\hline RNF & $\left(\begin{array}{l}.564 \\
(4.916)\end{array}\right.$ & $\begin{array}{c}-.104 \\
(-3.307)\end{array}$ & $\begin{array}{l}-3.649 \\
(-2.953)\end{array}$ & $\begin{array}{l}-5.621 \\
(3.976)\end{array}$ \\
\hline Town & $\left(\begin{array}{c}.201 \\
1.985\end{array}\right)$ & $\begin{array}{l}-.053 \\
(-1.925)\end{array}$ & $\begin{array}{l}-3.148 \\
(-2.889)\end{array}$ & $\begin{array}{l}-3.081 \\
(2.473)\end{array}$ \\
\hline Constant & 3.022 & .222 & 9.429 & 11.593 \\
\hline $\mathrm{R}^{2}$ & .087 & .058 & .049 & .048 \\
\hline
\end{tabular}

Note: $t$ statistics in parentheses 
This regression also indicates no significant French-English difference in family size. It is interesting to note that even for women whose families were completed in 1971, speaking French and living in Quebec had no significant effect on fertility, once religion, education, and other factors were held constant. In fact, the Quebec coefficient was negative. However, having a mother tongue other than French and English was associated with having significantly fewer children. Since this characteristic was hypothesized to lower the wage rate, to be consistent with the negative education coefficient it should have raised fertility. One possible explanation for this unexpected result may be that low fertility among immigrants is due to a selection process. Individuals with large tastes for children find emmigration too expensive, so immigrants to Canada, who constitute most of the "other" language groups, have lower tastes for children than their native counterparts. Another possible explanation suggested by Balakrishnan et al (1978), is simply that immigrants, raised in countries with lower birth rates than Canada, have tastes similar to their counterparts in their country of origins and lower than Canadian natives.

In the labour supply equations, greater education of the wife is associated with significantly increased labour supply for all three measures, labour force participation, usual hours worked per week, and weeks worked last year. This suggests that the two substitution effects of an increase in $w_{f^{--t h e ~}}$ substitution of goods intensive for time-intensive commodities and the substitution of market goods and husband's time for wife time in the production of home commodities-outweigh the positive income effect. Women in Ontario and the Prairie Provinces supply significantly more labour to the market than similar women in British Columbia, but differences among the other provinces are not significant. There also are no significant differences in labour supply among the three language groups, or between Catholics and non-Catholics. In terms of the model predictions, this implies that the substitution effect of an increase in $P_{x}$ in production $(\psi)$ 
(which tends to reduce $L^{f}$ ) about equals the sum of the income effect $\left(\eta_{J}\right)$ and substitution in consumption $(\sigma)$ (which tend to increase $L^{f}$ ).

The nonlabour income coefficient is insignificant in all three labour supply regressions, but the male wage has a large and significant negative effect on female labour supply. Finally, location in cities or on the farm is associated with greater quantities of labour being supplied, either to the market or, in the latter case presumably on the farm, though in the latter case it is hard to distinguish between home production and farm work.

\section{v. Logit and Tobit Results}

Thus far the estimation procedures have not taken account of the discrete nature of labour force participation and numbers of children nor of the concentration at zero of hours and weeks worked. Table 3 presents the marginal effects (at the means) of the independent variables on the probability of having an additional child, for samples of women with zero through five children. These were computed from $\beta_{i j} P_{j}\left(1-P_{j}\right)$ where $P_{j}$ is the fraction of women with $j$ children who have an additional child and $\beta_{i j}$ is $\operatorname{logit}$ coefficient of the $i^{\text {th }}$ independent variable from the fertility regression run on the sample of women with $j$ children. Table 4 presents similar marginal effects from a logit regression of labour force participation, and coefficients from Tobit regressions on hours and weeks worked.

The logistic fertility results are generally similar to the oLS coefficients presented in Table 2. Both imply that the effect of education on fertility is negative, and significant at most parity levels; that nonlabour income has no significant effect on fertility; that Catholics have significantly more children than non-Catholics: with the difference in probability of additional births increasing at each parity level; and that farm women have more children than rural nonfarm women, who have more children than women in small towns, who 
TABLE 3

"Logistic Fertility Equations: The Determinants of the Probability of an Additional Child at Varfous Parities"

\begin{tabular}{|c|c|c|c|c|c|c|}
\hline & $P(1)$ & $\mathrm{P}(2)$ & $\mathrm{P}(3)$ & $P(4)$ & $P(5)$ & $P(6)$ \\
\hline Variables & & & & & & \\
\hline $\mathrm{Ed}_{\mathbf{f}}$ & $\begin{array}{l}-.005 \\
(2.439)\end{array}$ & -.003 & $\begin{array}{l}-.010 \\
(2.562)\end{array}$ & $\begin{array}{l}-.010 \\
(1.799)\end{array}$ & $\begin{array}{l}-.015 \\
(2.257)\end{array}$ & $\begin{array}{l}-.012 \\
(1.374)\end{array}$ \\
\hline Newfoundland & $\left(\begin{array}{l}.051 \\
.814\end{array}\right)$ & $\begin{array}{l}.068 \\
(.983)\end{array}$ & $\begin{array}{l}.084 \\
(.948)\end{array}$ & $(1.126)$ & $\begin{array}{c}.365 \\
(2.294)\end{array}$ & $\begin{array}{c}.199 \\
(1.224)\end{array}$ \\
\hline Maritimes & $\begin{array}{l}-.017 \\
(.789)\end{array}$ & $\begin{array}{l}.010 \\
(.312)\end{array}$ & $\begin{array}{l}.008 \\
(.147)\end{array}$ & $\begin{array}{l}-.049 \\
(.690)\end{array}$ & $\begin{array}{c}.148 \\
(1.541)\end{array}$ & $\begin{array}{l}.037 \\
(.294)\end{array}$ \\
\hline Quebec & $\begin{array}{l}-.004 \\
(.184)\end{array}$ & $\begin{array}{l}-.030 \\
(1.129)\end{array}$ & $\begin{array}{c}-.065 \\
(1.346)\end{array}$ & $\begin{array}{l}-.019 \\
(.290)\end{array}$ & $\begin{array}{l}.064 \\
(.771)\end{array}$ & $\begin{array}{c}-.187 \\
(1.585)\end{array}$ \\
\hline Ontario & $\begin{array}{l}-.009 \\
(.622)\end{array}$ & -.001 & $\begin{array}{l}.007 \\
(.201)\end{array}$ & $\left(\begin{array}{l}.012 \\
.231)\end{array}\right.$ & $\left(\begin{array}{l}.041 \\
. .622)\end{array}\right.$ & $\begin{array}{l}-.070 \\
(.742)\end{array}$ \\
\hline Prairies & $\left(\begin{array}{l}.002 \\
.120\end{array}\right)$ & $\begin{array}{l}.015 \\
(.607)\end{array}$ & $\begin{array}{l}.031 \\
(.719)\end{array}$ & 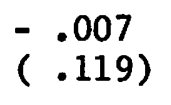 & $\left(\begin{array}{l}.007 \\
.097)\end{array}\right.$ & $\begin{array}{l}-.017 \\
(.158)\end{array}$ \\
\hline French & -.040 & $\begin{array}{l}.009 \\
(.374)\end{array}$ & $\begin{array}{c}.063 \\
(1.372)\end{array}$ & $\begin{array}{c}.059 \\
(1.000)\end{array}$ & -.014 & $\begin{array}{l}.062 \\
. .665)\end{array}$ \\
\hline Othlang & $\overline{(.008}(.541)$ & -.037 & $\begin{array}{l}-.124 \\
(3.869)\end{array}$ & $\overline{(.033}(.734)$ & $-(.019)$ & $\left(\begin{array}{l}.006 \\
.096)\end{array}\right.$ \\
\hline $\mathrm{W}_{\mathrm{m}}$ & $\begin{array}{c}.004 \\
(1.593)\end{array}$ & $\begin{array}{c}.010 \\
(3.001)\end{array}$ & $\begin{array}{l}-.004 \\
(1.656)\end{array}$ & $\begin{array}{l}-.000 \\
(.048)\end{array}$ & $\begin{array}{l}.005 \\
(.762)\end{array}$ & $\begin{array}{l}.001 \\
(.151)\end{array}$ \\
\hline Nlabinc & $\begin{array}{l}-.002 \\
(.706)\end{array}$ & $\begin{array}{c}.004 \\
(1.052)\end{array}$ & $\begin{array}{c}.068 \\
(1.144)\end{array}$ & $\begin{array}{l}.004 \\
(.749)\end{array}$ & $\begin{array}{l}.003 \\
(.304)\end{array}$ & $\begin{array}{l}-.009 \\
(.540)\end{array}$ \\
\hline Catholic & $\begin{array}{c}.048 \\
(2.970)\end{array}$ & $\begin{array}{c}.058 \\
(3.058)\end{array}$ & $\begin{array}{c}.087 \\
(2.926)\end{array}$ & $\begin{array}{c}.160 \\
(4.183)\end{array}$ & $\begin{array}{c}.108 \\
(2.344)\end{array}$ & $\begin{array}{c}.227 \\
(3.742)\end{array}$ \\
\hline Farm & $\begin{array}{c}.051 \\
(1.721)\end{array}$ & $(2.745)$ & $\begin{array}{c}.151 \\
(3.116)\end{array}$ & $\begin{array}{c}.234 \\
(4.014)\end{array}$ & $\begin{array}{c}.109 \\
(1.775)\end{array}$ & $\begin{array}{c}.170 \\
(2.138)\end{array}$ \\
\hline RNF & $\begin{array}{c}.034 \\
(1.955)\end{array}$ & $\begin{array}{c}.025 \\
(1.319)\end{array}$ & $\begin{array}{c}.088 \\
(2.565)\end{array}$ & $\begin{array}{c}.171 \\
(3.870)\end{array}$ & $\begin{array}{c}.110 \\
(2.109)\end{array}$ & $\begin{array}{c}.120 \\
(1.835)\end{array}$ \\
\hline Town & -.022 & $\begin{array}{l}.005 \\
.303)\end{array}$ & $\begin{array}{c}.056 \\
(1.895)\end{array}$ & $\begin{array}{c}.110 \\
(2.802)\end{array}$ & $\begin{array}{c}.087 \\
(1.803)\end{array}$ & $\begin{array}{c}.162 \\
(2.555)\end{array}$ \\
\hline Constant & $\left(\begin{array}{l}.220 \\
(7.742)\end{array}\right.$ & $\begin{array}{c}.168 \\
(4.677)\end{array}$ & $\begin{array}{c}.239 \\
(4.177)\end{array}$ & $\begin{array}{c}.078 \\
(1.036)\end{array}$ & $\begin{array}{l}.081 \\
(.825)\end{array}$ & $\begin{array}{l}.053 \\
(.406)\end{array}$ \\
\hline $\mathbf{P}$ & .908 & .867 & .705 & .645 & .623 & .602 \\
\hline NOBS & 2153 & 1955 & 1713 & 1208 & 779 & 485 \\
\hline L.R. & 12.87 & 17.75 & 38.51 & 44.60 & 20.25 & 22.06 \\
\hline
\end{tabular}

Note: Values are partial effects on the probability of having an additional child. Asymptotic $t$ statistics are in parentheses. $P(j)$ is the probability of the $j^{\text {th }}$ child given $j-1$ ehildren. 
TABLE 4

Tobit and Logit Labour Supply Results

\begin{tabular}{|c|c|c|c|}
\hline & LFP & Hours & Weeks \\
\hline \multicolumn{4}{|l|}{ Variables } \\
\hline $\mathrm{Ed}_{\mathrm{f}}$ & $\begin{array}{c}.020 \\
(5.134)\end{array}$ & $\begin{array}{l}1.354 \\
(4.521)\end{array}$ & $\begin{array}{r}1.852 \\
(5.024)\end{array}$ \\
\hline Newfoundland & $-(.007)$ & $\left(\begin{array}{l}-3.064 \\
(-.441)\end{array}\right.$ & $\begin{array}{c}-4.395 \\
(-.519)\end{array}$ \\
\hline Maritimes & $\begin{array}{l}.033 \\
(.631)\end{array}$ & $\begin{array}{l}7.199 \\
(1.712)\end{array}$ & $\begin{array}{c}1.589 \\
(.306)\end{array}$ \\
\hline Quebec & $\begin{array}{l}-.018 \\
(.391)\end{array}$ & $\begin{array}{c}-2.113 \\
(-.562)\end{array}$ & $\begin{array}{l}-7.335 \\
(-1.589)\end{array}$ \\
\hline Ontario & $\begin{array}{c}.107 \\
(3.568)\end{array}$ & $\left(\begin{array}{l}8.618 \\
2.970)\end{array}\right.$ & $\begin{array}{l}7.455 \\
(2.110)\end{array}$ \\
\hline Prairies & $\begin{array}{c}.084 \\
(1.953)\end{array}$ & $\begin{array}{l}9.386 \\
(2.781)\end{array}$ & $\begin{array}{l}5.855 \\
(1.419)\end{array}$ \\
\hline French & $\begin{array}{c}-.044 \\
(1.011)\end{array}$ & $\begin{array}{l}-1.214 \\
(-.357)\end{array}$ & $\begin{array}{c}-3.147 \\
(-.744)\end{array}$ \\
\hline Othlang & $\left(\begin{array}{c}.015 \\
.470)\end{array}\right.$ & $\begin{array}{l}2.546 \\
(1.057)\end{array}$ & $\begin{array}{l}3.765 \\
(1.276)\end{array}$ \\
\hline $\mathrm{w}_{\mathrm{m}}$ & $\begin{array}{l}-.012 \\
(3.173)\end{array}$ & $\begin{array}{c}-.416 \\
(-2.504)\end{array}$ & $\begin{array}{c}-.539 \\
(-2.654)\end{array}$ \\
\hline Nlabinc & $\begin{array}{c}-.001 \\
(.147)\end{array}$ & $\begin{array}{l}.298 \\
(\quad .668)\end{array}$ & $\begin{array}{l}.365 \\
(.668)\end{array}$ \\
\hline Catholic & $\begin{array}{c}-.033 \\
(1.181)\end{array}$ & $\begin{array}{c}-1.804 \\
(-.809)\end{array}$ & $\begin{array}{l}-2.146 \\
(-.780)\end{array}$ \\
\hline Farm & $\begin{array}{l}-.002 \\
(.058)\end{array}$ & $\begin{array}{l}7.108 \\
(2.219)\end{array}$ & $\left(\begin{array}{c}1.901 \\
(.478)\end{array}\right.$ \\
\hline RNF & $\begin{array}{l}-.122 \\
(3.634)\end{array}$ & $\begin{array}{c}-9.512 \\
(-3.590)\end{array}$ & $\begin{array}{l}-14.37 \\
(-4.353)\end{array}$ \\
\hline Town & $\begin{array}{l}-.059 \\
(2.073)\end{array}$ & $\begin{array}{c}-7.109 \\
(-3.099)\end{array}$ & $\begin{array}{c}-8.415 \\
(2.972)\end{array}$ \\
\hline Constant & -.277 & -13.01 & -16.47 \\
\hline $\mathbf{P}$ & .377 & & \\
\hline NOBS & & 2153 & 2153 \\
\hline L.R. & 65.78 & 62.77 & 69.63 \\
\hline
\end{tabular}


have more children that women in cities, at all parity levels.

There are, however, several interesting nonlinearities uncovered by the $\log$ it regressions. First, although the ols regression implies that women. in Newfoundland have on average 0.87 more children than comparable women in British Columbia, their probability of having an additional child, though larger, is only significantly larger among women with four children. The Newfoundland coefficients at other parities are insignificant as are al1 the other provincial logit coefficients.

The OLS results also mask nonlinearities in the relation between language and fertility. The OLS French coefficient is positive but insignificant, but French women are significantly more likely than English women to be childless. Among women with at least one child, the two groups show no significant differences in the probability of having additional children. By contrast, the OLS regression indicates that Other Language women have significantly fewer children than the English women, but the logit regressions indicate that differences in the probability of additional children are significant only for the second and third child. Finally, the effect of the husband's wage is positive but not significant in the OLS fertility regression, but this variable significantly increases the probability of a second child and significantly decreases the probability of a third child.

The signs and significance of the coefficients from the logit and Tobit regressions of the three labour supply variables are the same as the coefficients from the OLS regressions. However, although the logit and OLS labour force participation coefficients are quite close as expected the Tobit coefficients from the hours and weeks regressions are often twice the (absolute) size of the oLs coefficients. For example, the oLS results imply that Ontario women work 4.5 hours per week and 3.7 weeks per year more than similar women in 
British Columbia. The Tobit results imply a difference of 8.6 hours and 7.5 weeks. The OLS regressions suggest that a year of education increases labour supply by 0.53 hours and 0.75 weeks, while the Tobit regressions suggest increases of 1.35 hours and 1.85 weeks.

\section{CONCLUSIONS}

In this paper we have derived predictions from the Household Production Model of the allocation of time and fertility concerning the lifetime labour supply of women and completed family size. Empirical tests of this lifetime model were presented using 1971 Canadian Census Data. In the empirical Implementation of the model we have taken account of the discrete nature of the dependent variables, in the case of family size and labour force participation and the fact that observations may be concentrated at zero--for hours and weeks worked. The latter measures of labour supply proved to be quite sensitive to this correction.

Our results may be summarized as follows. There is little evidence that income variables (non-labour income and husband's wages) affect completed family size although the effect of the latter variable may be non-linear. These results are in agreement with the lack of any strong or systematic effect of these variables on completed family size that have been found in U.S. studies. The education of women has a strong negative effect on completed family size--implying that the substitution effect of an increased lifetime wage rate which raises the opportunity cost of having children outweighs any positive income effect. Since we also find that women's education increases all measures of labour supply this implies that education is market "biased" in the sense that it raises women's productivity in the labour market relative to that in home activities. The finding that women's education increases their 
labour supply implies, in the context of our model, that the labour supply schedule for women is positively sloped. In addition, we find evidence of a significant cross-price elasticity. An increase in the wage rate of the . husband significantly reduces the amount of labour supplied to the market by married women.

Location in urban areas has a significant impact on both labour supply and fertility. As one moves out of the large cities to small towns and farms family size increases, due to the lower costs of raising a family in the latter areas. Women located in large cities or faims supply more labour outside the home than women located in small towns or rural areas. For women located on farms this may represent more hours of work on the farm, rather than in the off-farm 1abour market. These results suggest that the secular increase in women's education and migration from rural areas to urban centres over the last decades have contributed both to the secular decline in family size and the increased labour supply of women.

The results summarized thus far suggest that the underlying relationships determining women's labour supply and fertility in Canada do not differ markedly from those of other developed nations. Other results are of interest in a purely Canadian context. Once location and religion are held constant we find very little difference in the fertility of Englishand French-speaking populations. French-speaking Canadians have a higher probability of remaining childless, but we find no significant difference in completed family size. However, minority language groups have smaller families once other factors are held constant. With the exception of Newfoundland, once other variables are held constant, completed family size does not differ across the provinces. The larger families observed in Newfoundland were found to be the result of the larger proportion of women 
having five or more children. Catholic women we found to have larger families.

In contrast to the lack of differences in completed family size be-tween provinces, significant differences in labour supply exist. Women located in Ontario and the Prairie provinces have higher rates of labour force participation and supply more hours and weeks to the labour market than women located in other provinces. These differences, which are sizeable, may be due to variations in the wages of women between provinces or other factors which we are unable to measure in these data.

In further work on this topic we plan to make use of panel data, which will allow us to obtain empirical measures of wages and other variables which correspond more closely to the lifetime variables implied by the theoretical model. Such data should permit additional insights into the determination of 1 ifetime labour supply and fertility. 


\section{Footnotes}

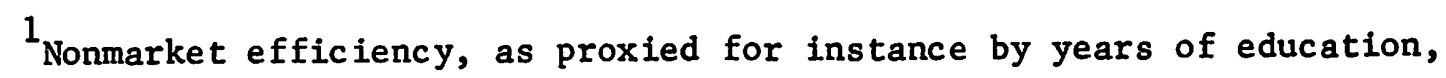
may also enter the household production functions (7) and (8). However, since these effects may be complex, no unambiguous predictions concerning this effect can be made. Therefore we abstract from this effect.

${ }^{2}$ See Carliner, Robinson, and Tomes (1978) for further discussion of this issue.

${ }^{3}$ See for example Rosenzweig and Evenson (1977).

${ }^{4}$ For workers, the hourly wage rate must be computed from Earn/ $(\mathrm{H} \cdot \mathrm{Wk})$ where Earn is last year's annual earnings, $H$ is hours usually worked per week prior to the Census survey, and Wh is the number of weeks worked during the previous year. $\mathrm{H}$ and $\mathrm{Wk}$ are only available in codes for large intervals. ${ }^{5}$ An exception is a "Comment" by McFadden (1975).

${ }^{6}$ Since women are assumed to work at some time in the life cycle, the concentration of the proxies for lifetime labour supply--"normal hours" and "weeks worked in the preceding year"--at zero implies that the proxy reaches zero before the true variable, and is truncated at that point. The Tobit procedure is designed to alleviate the bias that arises because of this problem. 


\section{$\underline{\text { References }}$}

Balakrishnan, T. R., Ebanks and Grindstaff (1978). "Fertility in Canada: Associations and Interpretations," (Monograph: The University of Western Ontario).

Balakrishnan, T. R., J. F. Kantner and J. D. Allingham (1975). "Fertility and Family Planning in a Canadian Metropolis," (Montreal and London: McGill-Queen's University Press.)

Becker, G. S. (1965). "A Theory of the Allocation of Time," Economic Journa1 75, 493-517.

Cain, G. and M. Dooley (1976). "Estimation of a Model of Labour Supply, Fertility and Wages of Married Women," Journal of Political Economy 84, S179-S199.

Carliner, G., C. Robinson and N. Tomes (1978). "A Simultaneous Equation Model of Female Labour Supply and Fertility," (Chicago: Meetings of the Econometric Society).

Collishaw, N. (1976). "Fertility in Canada: 1971 Census of Canada Profile," (Ottawa: Statistics Canada).

Conger, D. J., and J. M. Campbeil (1978). "Simultaneity in the Birth Rate Equation: The Effects of Education, Labour Force Participation, Income and Health," Econometrica 46, 631-641.

Da Vanzo, J. (1972). "The Determinants of Family Formation in Chile 1960: An Econometric Study of Female Labour Force Participation, Marriage and Fertility Decisions," Rand Report No. R 830 AID.

Davies, N. (1969). "Some Methods of Analyzing Cross-Classified Census Data: The Case of Labour Force Participation Rates," Special Labour Force Studies, Series B, No. 3, 1969.

Griliches, Z., B. H. Ha11 and J.A. Hausman (1977). "Missing Data and SelfSelection in Large Panels," Discussion Paper No. 573 (Harvard Instițte of Economic Research, 1977).

Gunderson, M. (Aug. 1977). "Logit Estimates of Labour Force Participation Based on Census Cross Tabulations," Canadian Joumal of Economics $10: 3$.

Heckman, James, (1977). "Sample Selection Bias As a Specification Error (With an Application to the Estimation of Labor Supply Functions)," (Center for Mathematical Studies in Business and Economics 1977), Report No. 7720.

Hecloman, James J. (1978). "A Partial Survey of Recent Research on the Labor Supply of Women." American Economic Review, May 1978. 
Henripin, Jacques, (1972). "Trends and Factors of Fertility in Canada," Ottawa: Statistics Canada 1972.

McFadden, D. (1975). "Comments on 'Estimation of a Stockastic Model of Reproduction: An Econometric Approach'," in Terlecky.z, N.E. (ed.), "Household Production and Consumption," NBER, New York, 1975.

Michael, Robert T. (1973). "Education in Nonmarket Production," Journa1 of Political Economy 81, pt. 1 (March/Apri1 1973): 306-27.

Ostry, S. (1968). "The Female Worker in Canada," 1961 Census Monograph.

Rosenzweig, M. and R. Evenson (1977), "Fertility, Schooling, and the Economic Contribution of Children in Rural India: An Econometric Analysis," Econometrica 45, pp. 1065-79, July 1977.

Schu1tz, T. P., K. Mauer and R. Ratajczak (1973). "Marriage, Fertility and Labour Force Participation of Thai Women: An Econometric Study," Rand Report No. R-829 - AID/RF (1973) Santa Monica: The Rand Corporation.

Schultz, T. W. (ed.), (1974) Economics of the Family, (Chicago: University of Chicago Press.

Shoulas, N. (1974). "Determinants of the Participation Rate of Married Women in the Canadian Labour Force: An Econometric Analysis," (Ottawa: Information Canada).

Spencer, Byron, (1973). "Determinants of the Labour Force Participation of Married Women: A Micro-Study of Toronto Households," Canadian Journa1 of Economics $6: 2$. May 1973 .

Willis, Robert, (1973). "Economic Theory of Fertility Behaviour," Journal of Political Economy, March/April 1973. 